\title{
Desenvolvimento de embriões de camundongas após manutenção em diferentes soluções de manipulação
}

\author{
[Development of mice embryos after maintenance in different manipulation solutions] \\ F.G. Lopes ${ }^{1}$, E.P. Costa ${ }^{2 *}$, E.C.M. Pereira ${ }^{1}$, T.A.R. Paula ${ }^{2}$, R.J.O. Arroyo ${ }^{1}$, \\ C.A.C. Fernandes ${ }^{3}$, G.G. Macedo ${ }^{1}$, A.H.A. Costa ${ }^{4}$ \\ ${ }^{1}$ Aluno de pós-graduação - DVT-UFV - Viçosa, MG \\ ${ }^{2}$ Departamento de Veterinária - UFV - Viçosa, MG \\ ${ }^{3}$ Biotran - Biotecnologia e Treinamento em Reprodução Animal - Alfenas, MG \\ ${ }^{4}$ Germovet - Biotecnologia em Reprodução Animal - Viçosa, MG
}

\begin{abstract}
RESUMO
Avaliou-se a eficácia de duas soluções de manipulação (SM) de embriões de camundongas nos estádios de blastocisto inicial (Bin), mórula compacta grau I (McI) e II (McII), distribuídos aleatoriamente em três tratamentos (T), de acordo com a solução de manutenção. No T1 usou-se PBS modificado (controle); no T2, SME e no T3, SME enriquecida. Os embriões foram mantidos durante quatro horas na solução de manutenção e posteriormente classificados quanto ao estádio de desenvolvimento e à qualidade embrionária. Logo após, foram cultivados em meio TCM 199 e classificados novamente quanto ao estádio de desenvolvimento e à qualidade embrionária. A taxa de desenvolvimento dos embriões após manutenção por quatro horas em solução de manipulação foi menor $(\mathrm{P}<0,05)$ nos embriões do controle, comparada à de embriões do SME e SME enriquecida, diferença esta não observada $(\mathrm{P}>0,05)$ após 0 cultivo in vitro. Os embriões McII do T3 tiveram maior desenvolvimento $(\mathrm{P}<0,05)$ em relação aos embriões do T1 e T2, indicando o efeito benéfico do enriquecimento da solução SME. Conclui-se que as soluções de manipulação SME e SME enriquecida influenciaram beneficamente o desenvolvimento de embriões.
\end{abstract}

Palavras-chave: camundonga, embrião, reprodução

\begin{abstract}
The effect of embryo manipulation solution followed by in vitro culture in mice embryos was studied. The embryos at early blastocyst (Bin), and compact morula grades I (McI) and II (McII) were randomly assigned into three treatments. T1 used modified PBS (control), T2 used EMS, and T3 used EMS supplemented. In each treatment, the embryos were kept in manipulation solution for four hours. Finishing the manipulation period, the embryos were classified according the development stage and quality. Following, the embryos were cultured in TCM 199. After the culture period, the embryos were evaluated according to quality and development stage. The development rate for Bin, McI, and McII after maintenance for four hours in manipulation solution was lower for control embryo (P>0.05) as compared to EMS and EMS supplemented embryos. After in vitro culture, no differences $(P>0.05)$ on embryo development rate among control, EMS, and EMS supplemented were observed. Moreover, McII from EMS supplemented had a higher development $(P<0.05)(93 \%)$ as compared to control (82.5\%) and EMS (83.9\%), suggesting a beneficial effect of EMS supplemented. EMS and EMS supplemented embryos had a positive effect on embryo development, showing higher embryo development than those in PBS solution.
\end{abstract}

Keywords: mouse, embryo, reproduction

Recebido em 16 de dezembro de 2009

Aceito em 6 de dezembro de 2010

*Autor para correspondência (corresponding author)

E-mail: epcosta@ufv.br 


\section{INTRODUÇÃO}

O estudo básico da morfologia de embriões, especialmente de camundongas e de bovinos, teve início a partir da década de 40. Nas espécies mamíferas, muitos eventos importantes ocorrem durante o desenvolvimento embrionário, desde a fase de zigoto até a formação do blastocisto. Isto inclui a primeira clivagem e a ativação do genoma embrionário, a qual ocorre no estádio de duas células para camundongas (Whittingham e Biggers, 1967) e de oito a 16 células para bovinos (Kanka et al., 2003. Além destes aspectos, ocorre a compactação da mórula e a formação do blastocisto, estabelecendo a diferenciação de dois tipos celulares, constituindo o trofoblasto (TF) e massa celular interna (MCI). O TF é composto por células externas do blastocisto, originando, posteriormente, as membranas extraembrionárias. As células da MCI originam o feto e contribuem, em parte, para a formação das membranas extraembrionárias (Lonergan et al., 2003).

De acordo com Van Soom et al. (1997) e Rizos et al. (2003), o desenvolvimento embrionário depende da capacidade do embrião em controlar o momento da expressão de cada gene responsável por uma fase específica do desenvolvimento, após a ativação do genoma. Diante disso, qualquer modificação nas condições de cultivo pode afetar um ou todos estes processos, tendo efeito na qualidade e, consequentemente, na viabilidade embrionária. Este critério, por sua vez, envolve aspectos relacionados à velocidade de determinados eventos morfológicos. Nesse contexto, inclui a duração mais curta ou mais longa do processo de compactação de mórulas, expansão mais lenta ou mais rápida da blastocele e diferenças no momento da eclosão (Gonzales e Bavister, 1995).

A manutenção do embrião em uma solução adequada, desde a coleta até a inovulação, é um aspecto importante, uma vez que pode interferir na qualidade e, consequentemente, na viabilidade embrionária (Bavister, 1995). De acordo com Vanroose et al. (2001), a escolha de meios e substratos energéticos tem impacto no desenvolvimento e na viabilidade de embriões.

Atualmente, a solução de manipulação rotineiramente empregada na transferência de embriões (TE) em bovinos tem sido o PBS modificado (Whittingham, 1971). Essa solução fosfatada tamponada (PBS) foi formulada por Dulbecco e Vogt para uso em manipulação de cultivos bacterianos e, posteriormente, modificada por Whittingham (1971), para a manipulação de embriões de camundongas. Com o sucesso obtido pelo pesquisador, poucos estudos foram realizados no intuito de encontrar soluções mais apropriadas e estáveis para a manipulação de embriões nas diferentes espécies animais.

O PBS modificado (Whittingham, 1971), entretanto, está sujeito a eventuais mudanças na composição, como variações de $\mathrm{pH}$, quando armazenado por longos períodos em temperatura e luz ambientes (Gordon, 1994). O cloreto de cálcio e o de magnésio podem formar precipitados quando o meio é submetido ao processo de congelação (Manual..., 1998). Portanto, a solução deve ser armazenada em local com pouca luminosidade e refrigerado.

O objetivo deste trabalho foi avaliar o efeito de diferentes soluções de manipulação no subsequente desenvolvimento embrionário.

\section{MATERIAL E MÉTODOS}

O trabalho foi realizado com embriões de camundongas da espécie Mus musculus, da linhagem Suíça-Albina. $\mathrm{O}$ protocolo de superovulação e coleta de embriões foi realizado segundo Rafferty Jr. (1970). Os procedimentos relacionados aos animais foram aprovados pela Comissão de Ética do Departamento de Veterinária da UFV, processo 10/2006, em reunião realizada no dia 26 de abril de 2006.

Foram testadas duas soluções de manipulação (SM) utilizadas para coleta e manipulação de embriões, SME (em processo de patenteamento) e SME enriquecida (em processo de patenteamento), e, como controle, o PBS modificado (Whittingham, 1971), usualmente empregado nas rotinas de TE nas diferentes espécies animais.

As soluções SME e SME enriquecida foram produzidas e ajustadas com glicose para 290 mOsm, com o auxílio de um osmômetro (Osmette $\mathrm{A}^{\circledR}$ Automatic Osmometer), e o pH ajustado para 7,2 a 7,4. Após o ajuste, a concentração de glicose em cada solução foi 
definida, utilizando-se o osmômetro apenas para o monitoramento das soluções preparadas ao longo do experimento. Todos os reagentes empregados para a produção das soluções de manipulação e de cultivo foram testados para cultivo celular. Além disso, os antibióticos utilizados para as soluções SME e SME enriquecida foram os mesmos usados no PBS modificado (Whittingham, 1971).

Para o estudo, foram utilizados apenas embriões nos estádios de blastocisto inicial (Bin), mórula compacta grau I (McI) e II (McII), distribuídos aleatoriamente em três tratamentos. No T1, usouse o PBS modificado (controle); no T2, a SME e no T3, a SME enriquecida.

Os embriões de cada tratamento foram mantidos em placas de quatro poços (Nunc ${ }^{\circledR} \mathrm{A} / \mathrm{S}$ ), durante quatro horas, em solução de manipulação, previamente equilibrada $\left(37^{\circ} \mathrm{C}\right)$ e acrescida de $0,4 \%$ de albumina sérica bovina (BSA), fração V.

Após o tempo de manipulação, os embriões foram classificados quanto ao estádio de desenvolvimento e à qualidade embrionária (Manual..., 1998), com o auxílio de um microscópio estereoscópio (Olympus Optical ${ }^{\circledR}$, modelo SZ-40/ SZ-ST) em ocular de 10X e objetiva de 4X. Depois de classificados, os embriões foram transferidos e cultivados em placas de quatro poços (Nunc ${ }^{\circledR} \mathrm{A} / \mathrm{S}$ ), durante 10 horas, em meio de cultivo TCM 199 modificado (Costa et al., 1997), previamente equilibrado $\left(37^{\circ} \mathrm{C}\right)$, em atmosfera de $5 \%$ de dióxido de carbono $\left(\mathrm{CO}_{2}\right)$, $95 \%$ de ar atmosférico e $95 \%$ de umidade em estufa incubadora (Jouan ${ }^{\circledR}$, modelo IG 150).

Após o tempo de cultivo, os embriões foram transferidos e lavados em placa escavada, em meio Talp-Hepes modificado (Costa et al., 1997), previamente equilibrado $\left(37^{\circ} \mathrm{C}\right)$. Foram classificados novamente quanto ao estádio de desenvolvimento e à qualidade embrionária (Manual..., 1998), com o auxílio de um microscópio estereoscópio (Olympus Optical ${ }^{\circledR}$, modelo SZ-40/ SZ-ST) em ocular de 10X e objetiva de $4 X$.

As variáveis qualitativas foram comparadas em tabelas de contingência e analisadas pelo teste do qui-quadrado a $5 \%$ de probabilidade (Sampaio, 2002).

\section{RESULTADOS E DISCUSSÃO}

Após a manutenção, por quatro horas, em solução de manipulação, verificou-se uma menor taxa de desenvolvimento $(\mathrm{P}<0,05)$ em embriões do tratamento-controle, independentemente da classificação inicial (Bin, McI ou McII). Estes resultados demonstram a superioridade das soluções propostas em relação ao PBS modificado, aspecto já apontado por Whittingham (1971) (Tab. 1, 2 e 3). Uma das prováveis explicações para essas diferenças pode estar relacionada à disponibilidade e às concentrações de substratos energéticos presentes nas soluções de manipulação (Rieger, 1992; Bavister, 1995; Donnay e Leese, 1999; Thompson, 2000). De acordo com Vanroose et al. (2001), a escolha de meios e substratos energéticos tem impacto direto no desenvolvimento e na viabilidade de embriões.

Para Lonergan et al. (2003) e Rizos et al. (2003), o cultivo in vitro é uma condição crítica, pois pode alterar o padrão de expressão gênica e, assim, comprometer a qualidade e a sobrevivência após a transferência de embriões em estádio pré-implantacional. Khurana e Niemann (2000) verificaram que alterações encontradas em embriões produzidos in vitro podem estar relacionadas principalmente às condições adversas de cultivo, às quais os embriões são expostos. Nesse contexto, Ménézo et al. (1998) verificaram que a utilização de um único meio de cultivo (cocultura de células da tuba uterina e da granulosa), da fecundação até o estádio de blastocisto, resultou em baixa taxa de blastocistos (50\%) e implantação de blastocistos transferidos (25\%), e para Bavister (2000), esse fato aponta para a inadequação do meio de cultivo em proporcionar o desenvolvimento normal aos estádios embrionários iniciais. Adicionalmente, há comprovações científicas suficientes indicando que, por melhores que sejam, as condições de desenvolvimento in vitro não são capazes de substituir todos os benefícios do desenvolvimento embrionário no trato reprodutivo (Bavister, 2000).

Os embriões podem secretar diversos compostos com concentrações variáveis, de acordo com suas especializações, nutrição ou tempo de manipulação. Segundo Donnay e Leese (1999), os substratos energéticos, como glicose, piruvato e lactato, desempenham relevante papel no 
desenvolvimento embrionário e, por isso, são utilizados nas diferentes soluções de cultivo. Assim, o desenvolvimento do embrião é comprometido na ausência desses substratos (Kim et al., 1993; Rosenkrans et al., 1993).

No presente estudo, as soluções de manipulação foram constituídas de diferentes substratos energéticos. O PBS modificado (Whittingham, 1971) contém em sua formulação os substratos energéticos glicose e piruvato, enquanto a SME possui glicose e lactato. A solução SME enriquecida contém três substratos energéticos: glicose, piruvato e lactato. Conforme descrito por Gordon (1994) e Bavister (1995), essa interação de substratos pode ter sido responsável pelos resultados apresentados de desenvolvimento embrionário.

A elaboração das soluções propostas fundamentou-se na predileção do embrião ao piruvato e lactato nas fases iniciais de desenvolvimento embrionário e na necessidade da incorporação da glicose nas fases finais de desenvolvimento do embrião (Bavister, 1995; Thompson, 2000). A escolha do piruvato foi amparada pelo fato de essa substância ser utilizada pelos embriões ao longo de seu desenvolvimento. Ocorre um aumento de suas necessidades após a blastulação, sendo esse aumento essencial para a viabilidade do blastocisto (Dorland et al., 1992). Rieger (1992) e Martin e Leese (1995) mostraram que $44 \%$ do piruvato, captado pelo embrião, são metabolizados no estádio de duas células e $17 \%$ na fase de mórula. Nessa fase, a glicose é o substrato mais utilizado, enquanto em fases anteriores do desenvolvimento, o seu consumo é mínimo. Segundo Bavister (1995), o embrião utiliza o lactato deste o estádio de uma célula até blastocisto, sugerindo que o embrião possui, desde o estádio inicial, as enzimas necessárias para a atividade glicolítica. Somado a isso, a interação entre piruvato e lactato é essencial para o balanço do potencial oxidação/redução (Morales et al., 1999). A presença da glicose na solução de manipulação se justifica, pois a utilização desse componente é imprescindível para a sobrevivência e o desenvolvimento do embrião durante o período de pré-implantação. O decréscimo na captação de glicose durante o estádio de blastocisto pode comprometer o desenvolvimento o desenvolvimento embrionário (Riley e Moley, 2006).

Tabela 1. Taxa de desenvolvimento de embriões Bin após manutenção por quatro horas em diferentes soluções de manipulação

\begin{tabular}{cccc}
\hline \multirow{2}{*}{ Tratamento } & Total de embriões & \multicolumn{2}{c}{ Desenvolvimento embrionário } \\
\cline { 3 - 4 } & & $\mathrm{N}$ & $\%$ \\
\hline Controle & 153 & 66 & $43,1 \mathrm{a}$ \\
SM & 183 & 125 & $68,3 \mathrm{~b}$ \\
SM enriquecida & 164 & 96 & $58,5 \mathrm{~b}$
\end{tabular}

Controle: PBS modificado (Whittingham, 1971).

Valores com letras distintas na mesma coluna indicam diferença $(\mathrm{P}<0,05)$ entre tratamentos, pelo teste do quiquadrado.

Tabela 2. Taxa de desenvolvimento de embriões McI após manutenção por quatro horas em diferentes soluções de manipulação

\begin{tabular}{cccc}
\hline \multirow{2}{*}{ Tratamento } & \multirow{2}{*}{ Total de embriões } & \multicolumn{2}{c}{ Desenvolvimento embrionário } \\
\cline { 3 - 4 } & 243 & 70 & $\%$ \\
\hline Controle & 226 & 118 & $28,8 \mathrm{a}$ \\
SM & 171 & 87 & $52,2 \mathrm{~b}$ \\
SM enriquecida & & $50,9 \mathrm{~b}$
\end{tabular}

Controle: PBS modificado (Whittingham, 1971).

Valores com letras distintas na mesma coluna indicam diferença $(\mathrm{P}<0,05)$ entre tratamentos, pelo teste do quiquadrado. 
Lopes et al.

Tabela 3. Taxa de desenvolvimento de embriões McII após manutenção por quatro horas em diferentes soluções de manipulação

\begin{tabular}{cccc}
\hline \multirow{2}{*}{ Tratamento } & Total de embriões & \multicolumn{2}{c}{ Desenvolvimento embrionário } \\
\cline { 3 - 4 } & 151 & 13 & $\%$ \\
\hline Controle & 143 & 47 & $3,6 \mathrm{a}$ \\
SM & 115 & 36 & $32,9 \mathrm{~b}$ \\
SM enriquecida & & $31,3 \mathrm{~b}$
\end{tabular}

Controle: PBS modificado (Whittingham, 1971).

Valores com letras distintas na mesma coluna indicam diferença $(\mathrm{P}<0,05)$ entre tratamentos, pelo teste do quiquadrado.

Não foi observada diferença $(\mathrm{P}>0,05)$ na taxa de desenvolvimento de embriões Bin e McI, após a manutenção dos mesmos nas soluções e posterior cultivo in vitro. Isto indica que os embriões se desenvolvem normalmente após o cultivo, independentemente da solução de manutenção (Tab. 4, 5 e 6). Contudo, os embriões McII da SME enriquecida tiveram maior desenvolvimento $\quad(\mathrm{P}<0,05) \quad(93 \%), \quad$ quando comparados com os embriões do controle $(82,5 \%)$ e da SME (83,9\%), indicando o efeito benéfico do enriquecimento da solução SME para embriões de pior qualidade morfológica.

A razão pela qual as clivagens mais rápidas em embriões com maior capacidade de desenvolvimento ainda é desconhecida (Watson e Barcroft, 2001). Um dos mecanismos propostos para explicar estes resultados está na influência da solução SME enriquecida em manter um ambiente favorável aos embriões, estimulando assim, as células totipotentes viáveis (cerca de 50\%) (Manual..., 1998), recompondo com maior rapidez a população de células viáveis da massa celular. Provavelmente, a interação dos substratos energéticos (glicose, piruvato e lactato) presentes na solução SME enriquecida pode ter sido determinante para o maior desenvolvimento embrionário. Os resultados superiores encontrados em embriões expostos à SME enriquecida podem ainda estar relacionados à provável redução do número de blastômeros que sofrem morte celular, como demonstrado por Brison e Schultz (1997).

Tabela 4. Taxa de desenvolvimento de embriões Bin após manutenção em diferentes soluções de manipulação e posterior cultivo in vitro por 10 horas

\begin{tabular}{cccc}
\hline \multirow{2}{*}{ Tratamento } & Total de embriões & \multicolumn{2}{c}{ Desenvolvimento embrionário } \\
\cline { 3 - 4 } & & $\mathrm{N}$ & $\%$ \\
\hline Controle & 153 & 149 & 97,4 \\
SM & 183 & 175 & 95,6 \\
SM enriquecida & 164 & 151 & 92,1 \\
\hline
\end{tabular}

Controle: PBS modificado (Whittingham, 1971).

As diferenças não foram significativas $(\mathrm{P}>0,05)$ pelo teste do qui-quadrado.

Tabela 5. Taxa de desenvolvimento de embriões McI após manutenção em diferentes soluções de manipulação e posterior cultivo in vitro por 10 horas

\begin{tabular}{cccc}
\hline \multirow{2}{*}{ Tratamento } & \multirow{2}{*}{ Total de embriões } & \multicolumn{2}{c}{ Desenvolvimento embrionário } \\
\cline { 3 - 4 } & & $\mathrm{N}$ & $\%$ \\
\hline Controle & 243 & 232 & 95,5 \\
SM & 226 & 204 & 90,3 \\
SM enriquecida & 171 & 159 & 93,0 \\
\hline
\end{tabular}

Controle: PBS modificado (Whittingham, 1971).

As diferenças não foram significativas $(\mathrm{P}>0,05)$ pelo teste do qui-quadrado. 
Tabela 6. Taxa de desenvolvimento de embriões McII após manutenção em diferentes soluções de manipulação e posterior cultivo in vitro por 10 horas

\begin{tabular}{cccc}
\hline \multirow{2}{*}{ Tratamento } & \multirow{2}{*}{ Total de embriões } & \multicolumn{2}{c}{ Desenvolvimento embrionário } \\
\cline { 3 - 4 } & & $\mathrm{N}$ & $\%$ \\
\hline Controle & 151 & 124 & $82,5 \mathrm{a}$ \\
SM & 143 & 120 & $83,9 \mathrm{a}$ \\
SM enriquecida & 115 & 107 & $93,0 \mathrm{~b}$ \\
\hline
\end{tabular}

Controle: PBS modificado (Whittingham, 1971).

Valores com letras distintas na mesma coluna indicam diferença $(\mathrm{P}<0,05)$ entre tratamentos, pelo teste do quiquadrado.

\section{CONCLUSÕES}

As soluções de manipulação SME e SME enriquecida influenciam beneficamente no desenvolvimento de embriões, apresentando superioridade, quando comparadas à solução PBS modificado.

\section{AGRADECIMENTOS}

À FAPEMIG, pelo apoio financeiro; à CAPES, pela concessão da bolsa de estudo e à Germovet, pela cessão de materiais para a realização deste estudo.

\section{REFERÊNCIAS BIBLIOGRÁFICAS}

BAVISTER, B.D. Culture of preimplantation embryos: facts and artifacts. Human Reprod. Update, v.1, p.91-148, 1995.

BAVISTER, B.D. Interactions between embryos and the culture milieu. Theriogenology, v.53, p.619-626, 2000.

BRISON, D.R.; SCHULTZ, R.M. Apoptosis during mouse blastocyst formation: evidence for a role for survival factors including transforming growth factor alpha. Biol. Reprod., v.56, p.10881096, 1997.

COSTA, E.P.; VALE FILHO, V.R.; NOGUEIRA, J.C. et al. Cultivo in vitro de ovócitos bovinos em diferentes sistemas: I efeito na maturação nuclear. Arq. Bras. Med. Vet. Zootec., v.49, p.551-559, 1997.

DONNAY, I.; LEESE, H.J. Embryo metabolism during the expansion of the bovine blastocyst. Mol. Reprod. Develop., v.53, p.171-178, 1999.

DORLAND, M.; KRUIP, T.A.M.; VAN DER DONK, J.A. Assessing day 7 bovine embryo viability by measuring the rate of nutrient uptake. J. Reprod. Fertil., v.9, p.40, 1992.

GONZALES, D.S.; BAVISTER, B.D. Zona pellucida escape by hamster blastocysts in vitro is delayed and morphologically different compared with zona escape in vivo. Biol. Reprod., v.52, p.470-480, 1995.

GORDON, I. Laboratory production of cattle embryos. Cambridge, UK: CAB International, n.11, 1994. 640p.

KANKA, J.; BRYOVA, A.; DURANTHON, V. et al. Identification of differentially expressed mRNA in bovine preimplantation embryos. Zygote, v.11, p.43-52, 2003.

KHURANA, N.K.; NIEMANN, H. Effects of cryopreservation on glucose metabolism and survival of bovine morulae and blastocysts derived in vitro or in vivo. Theriogenology, v.54, p.313-326, 2000.

KIM, J.H.; NIWA, K.; LIM, J.M. et al. Effects of phosphate, energy substrates, and amino acids on development of in vitro-matured, in vitrofertilized bovine oocytes in a chemically defined, protein-free culture medium. Biol. Reprod., v.48, p.1320-1325, 1993.

LONERGAN, P.; RIZOS, D.; GUTIÉRREZADÁN, A. et al. Temporal divergence in the pattern of messenger RNA expression in bovine embryos cultured from the zygote to blastocyst stage in vivo or in vitro. Biol. Reprod., v.69, p.1424-1431, 2003.

MANUAL da Sociedade Internacional de Transferência de Embriões. 3.ed. Savoy, Illinois: International Embryo Transfer Society, 1998. 180p.

MARTIN, K.L.; LEESE, H.J. Role of glucose in mouse preimplantation embryo development. Mol. Reprod. Develop., v.40, p.436-443, 1995. 
MÉNÉZO, Y.; VEIGA, A.; BENKHALIFA, M. Improved methods for blastocyst formation and culture. Human Reprod., v.13, suppl.4, p.256265, 1998.

MORALES, H.; TILQUIN, P.; REES, J.F. et al. Pyruvate prevents peroxide-induced injury of in vitro preimplantation bovine embryos. Mol. Reprod. Develop., v.52, p.149-157, 1999.

RAFFERTY Jr., K.A. Methods in experimental embriology of the mouse. Baltimore: The Johns Hopkins, 1970. 78p.

RIEGER, D. Relationships between energy metabolism and development of early mammalian embryos. Theriogenology, v.37, p.75-93, 1992.

RILEY, J.K.; MOLEY, K.H. Glucose utilization and the PI3-K pathway: mechanisms for cell survival in preimplantation embryos. Reproduction, v.131, p.823-835, 2006.

RIZOS, D.; GUTIERREZ-ADAN, A.; PEREZGARNELO, S. et al. Bovine embryo culture in the presence or absence of serum: implications for blastocyst development, cryotolerance, and messenger RNA expression. Biol. Reprod., v.68, p.236-243, 2003.

ROSENKRANS Jr., C.F.; ZENG, G.Q.; McNAMARA, G.T. et al. Development of bovine embryos in vitro as affected by energy substrates. Biol. Reprod., v.49, p.459-462, 1993.
SAMPAIO, I.B.M. Estatística Aplicada à Experimentação Animal. 2.ed. Belo Horizonte: FEPMVZ, 2002. 265p.

THOMPSON, J.G. In vitro culture and embryo metabolism of cattle and sheep embryos - a decade of achievement. Anim. Reprod. Sci., v.6061, p.263-275, 2000.

VANROOSE, G.; VAN SOOM, A.; DE KRUIF, A. From co-culture to defined medium: State of the art and practical considerations. Reprod. Domest. Anim., v.36, p.25-28, 2001.

VAN SOOM, A.; YSEBAERT, M.T.; DE KRUIF, A. Relationship between timing of development, morula morphology and cell allocation to inner cell mass and trophectoderm in vitro produced bovine embryos. Mol. Reprod. Develop., v.47, p.47-56, 1997.

WATSON, A.J.; BARCROFT, L.C. Regulation of blastocyst formation. Front. Biosci., v.6, p.708-730, 2001.

WHITTINGHAM, D.G.; BIGGERS, J.D. Fallopian tube and early cleavage in the mouse. Nature, v.213, p.942-943, 1967.

WHITTINGHAM, D.G. Culture of mouse ova. $J$. Reprod. Fertil., v.48, Suppl.14, p.7-21, 1971. 